УДК 342.925:347.91(477)

\author{
C. B. Kiвaros
}

\title{
ПОНЯТІЙНО-ПРАВОВА ХАРАКТЕРИСТИКА СТОРІН ЯК УЧАСНИКІВ АДМІНІСТРАТИВНОГО СУДОЧИНСТВА
}

Судовий захист $є$ однією з найефективніших форм захисту прав, свобод, законних інтересів фізичних і юридичних осіб, оскільки тільки він дозволяє забезпечити максимально широкі мож.ливості безпосередньої участі зашікавлених осіб у вирішенні існуючого між ними спору про право, унаслідок чого забезпечується безконфліктність правовідносин, а отже, створюються умови для подальшого поступового якісного їх розвитку, отримання правосудного рішення, що гарантує законність і правопорядок у державі, для відновлення порушеного права. Саме тому набувають теоретичного та соціального значення наукові напрацювання, спрямовані на визначення шляхів удосконалення судового захисту. Це стосується всіх форм судочинства, насамперед адміністративного, оскільки саме публічно-правова сфера, зважаючи на наявність «перетинання» інтересів держави та приватної особи, від початку містить численні суперечності.

Варто відзначити, що діалектика розвитку суспільства пов'язана 3 постійним виникненням і розв'язанням конфліктів на різних рівнях та в різних сферах функціонування суспі.льства. Конфлікт $\epsilon$ способом виявлення та розв'язання суперечностей, шо виникають у суспільстві. Часто в літературі конфлікт визначається як прояв об'єктивних чи суб'єктивних суперечностей, шо виражаються в протиборстві сторін [1, с. 31], конфліктом вважається така ситуація, коли сторони взаємодії переслідують будь-які свої цілі, шо суперечать чи взаємно виключають олна одну [2, с. 44].

Врегулювання значної частини суспі.тьних відносин нормами права відповідних галузей також створює середовище для виникнення соціальних конфліктів. Проте сфера виникнення соціального конфлікту надає йому особливих якостей, у зв'язку із чим доцільно виокремлювати специфічний різновид соціального конфлікту - конфлікт юридичний. $\mathrm{У}$ найбільш широкому значенні під юридичним конфліктом розуміють будьякий соціальний конфлікт, у якому протиборство так чи інакше пов'язано з правовими відносинами сторін (iх юридично значушими діями чи станами), тому суб́'єкти, мотивація ї поведінки або об'єкт конфлікту 
мають правові ознаки, а конфлікт зумовлює юридичні наслідки [3, с. 15]. Виходячи $з$ такого визначення юридичного конфлікту, можна стверджувати, шо більшість соціальних конфліктів може бути трансформованою в юридичні конфлікти. Інакше кажучи, за допомогою юридичних норм та інститутів можна втрутитися в розвиток майже будь-яких подій. Таким чином, конфлікт виникає поза межами й незалежно від правових норм і відносин та тільки потім набуває юридичного характеру. Цей підхід дозволив В.Н. Кудрявцеву сформувати теорію змішаних або перехідних форм юридичного конфлікту [4, с. 126].

Виникнення юридичного конфлікту зумовлено юридичними ситуаціями й розв'язується юридичними засобами. У такому конфлікті суперечності й інтереси сторін порівнюються відповідно до встановлених правових норм, а він сам являє собою обмін домаганнями й запереченнями, шо мають юридичне значення. Інакше кажучи, конфлікт безпосередньо пов'язаний із реалізацією правових норм (їх диспозицій - закріплених у них суб'єктивних прав, юридичних обов'язків, повноважень чи їх санкцій) чи із самими правовими нормами (їх законністю чи тлумаченням) [3, с. 22].

У більшшості випадків дії щодо вирішення конфліктів формалізовано вілповідними юридичними процедурами. У науковій літературі навіть пропонується вважати розв'язання конфлікту за допомогою юридичних процедур обов'язковою умовою визнання конфлікту юридичним $[5$, с. 238]. Безумовно, наявність процедур вирішення конфліктів спрямована на вирішення спору відповідно до правових приписів, запобігає наданню такому конфлікту деструктивного характеру, порушенню режиму законності, а протікання конфлікту в інший спосіб, поза встановленим порядком розв'язання, здатне призвести до негативних суспільних наслідків та не гарантує легітимності отриманих у такій спосіб результатів [6, с. 44]. Проте відсутність установлених процедур щодо вирішення конфлікту не позбавляє його ознак юридичного, оскільки сторони конфлікту від цього не перестають бути носіями правового статусу, учасниками правовідносин тошо.

Категорія «публічно-правовий спір» більшістю вчених розглядається в контексті юридичного конфлікту. Водночас чіткого визначення характеру співвідношення цих понять у літературі й досі не вироблено. Одні вчені розглядають публічно-правовий спір як різновид юридичного конфлікту, інші - як стадію розвитку юридичного конфлікту. Існує також підхід, згідно $з$ яким публічно-правовий спір $є$ формою розвитку юридичного конфлікту. У теорії адміністративного процесу найбільшого поширення набула позиція А.Ю. Осадчого, згідно з якою правовий спір визначається як втілене в юридично значуших діях протиборство суб'єктів права у зв'язку з нормами права чи з їх реалізацією [7, с. 116]. Важливо зазначити, що втілюється такий конфлікт у діях його сторін, що зумовлюють для них правові наслідки. Вчинення цих дій передбачено правовими нормами й насамперед спрямоване на вирішення спору відповідно до правових приписів.

На думку А.Ю. Осадчого, правові спори можна поділяти на різновиди за такими критеріями: 
1) залежно від предмета спору, тобто від того, заради чого суб'єкти вступають у протиборство, виокремлюються такі основні різновиди правового спору: а) спори з приводу реалізашії закріплених у нормах права суб'єктивних прав, законних інтересів, повноважень, обов'язків тошо; б) спори з приводу норм права ї тлумачення або законності; в) спори 3 приводу правопорушень - щодо наявності в діянні особи складу певного делікту та, відповідно, застосування до винної особи санкції правової норми;

2) залежно від поділу системи права на приватне та публічне право виокремлюють правові спори у сфері публічного права та у сфері приватного права $[7$, с. 116].

Обов'язковим елементом будь-якого публічно-правового спору $\epsilon$ його суб'єкти (учасники). Враховуючи те, шо публічно-правові спори $є$ різновидом юридичного конфлікту, чинним законодавством передбачено способи ï вирішення, можна дійти висновку, що сторони пубблічно-правового спору є потенційними сторонами адміністративного судочинства, які можуть набути відповідного статусу в разі виявлення однією зі сторін ініціативи та дотримання передбачених законодавством умов.

Перш ніж розпочати дослідження поняття сторін в адміністративному судочинстві та здійснити ї класифікашію, треба визначити та розмежувати всіх учасників адміністративного судового процесу взагалі. Правове становище учасників адміністративного судочинства регламентоване главою 5 Кодексу адміністративного судочинства України (далі - КАС України) [8]. Нормами цієї глави встановлено склад учасників адміністративного судочинства та їхні процесуальні права й обов'язки.

Під час розгляду питання про учасників адміністративного судочинства насамперед необхідно зупинитися на співвідношенні декількох окремих понять, які використовуються в КАС України. По-перше, це стосується таких понять, як «учасники адміністративного судочинства» Та «учасники адміністративного процесу». Відомо, шо термін «адміністративний процес» трактується в юридичній літературі неоднозначно. Не вдаючись до дискусї щодо поняття адміністративного процесу в широкому, вузькому чи іншому розумінні, варто сказати, що в контексті цієї роботи адміністративний процес розглядається відповідно до його законодавчого визначення, тобто як правовідносини, що складаються під час здійснення адміністративного судочинства (ст. $3 \mathrm{KAC} \mathrm{України).} \mathrm{Згідно} \mathrm{зі} \mathrm{ст.} 3 \mathrm{KAC} \mathrm{України} \mathrm{адміністратив-}$ не судочинство визначається як діяльність адміністративних судів шодо розгляду й вирішення адміністративних справ у порядку, встановленому шим кодексом, тобто учасниками адміністративного (судового) процесу $\epsilon$ учасники правовідносин, що виникають, змінюються та припиняються під час здійснення адміністративним судом розгляду та вирішення адміністративних справ у порядку, встановленому КАС України. Враховуючи вищевикладене, можна зробити висновок про тотожність понять «учасники адміністративного судочинства» та «учасники адміністративного (судового) процесу». 
У юридичній літературі наголошується також на необхідності розмежування понять «учасники процесу» та «суб'єкти процесу» $[9$, с. 86]. Як правило, під терміном "суб'єкти процесу» розуміють усіх без винятку осіб, шо беруть участь у прошесі, включаючи лідируючого суб' $є$ кта, який саме здійснює розгля справи, визначає іï хід і приймає остаточне рішення в справі. Під час здійснення адміністративного судочинства таким лідируючим суб'єктом є адміністративний суд. Що ж стосується терміна «учасники процесу», то він $є$ значно вужчим та охоплює тих осіб, які вступають до адміністративного процесу для захисту свої прав і законних інтересів, захисту прав і законних інтересів інших осіб або з метою сприяння зјійсненню адміністративного процесу. Безумовно, ші особи наділені всіма необхідними правами для впливу на хід процесу, проте вирішальна роль належить лідируючим суб'єктам процесу $[9$, c. 86$]$

Досліджуючи проблему сутності співвідношення понять «суб'єкти процесу (провадження)» та «учасники процесу (провадження)», О.В. Кузьменко пропонує визначити суб́ 'єкт адміністративного процесу як носія прав та обов'язків з реалізації процесуальної діяльності у сфері публічного управління, здатним надані права шодо процесуальної діяльності реалізовувати, а покладені обов'язки виконувати. Учасником адміністративного процесу учений пропонує визначити реально існуючого індивіда адміністративного процесу [10 с. 175].

Виокремлення суб'єкта й учасника адміністративного процесу через відповідну його участь (потенційну чи реальну) у певній процесуальній діяльності неоднозначно сприймається суддями, оскільки і суб'єкти, i учасники набувають певного статусу та реалізують його в процесуальних правовідносинах. При цьому об́є єднючою категорією постає суб'єкт адміністративного процесуального права як абстрактна особа в соціально-правовому змісті.

О.В. Бачун пропонує загальне визначення поняття «суб'єкт адміністративного судочинства»: особ́ (фізична чи юридична) - носій (потенційного або реального) прав та обов'язків в адміністративних процесуальних відносинах із приводу відправлення правосуддя адміністративними судами, здатна змінити процесуальними діями стадії судочинства та його завершення. Суб'єктом адміністративного судочинства постає особа, здатна вступати в такі відносини, реалізовувати вказані права та виконувати обов'язки, які суттєво впливають на процесуальну діяльність суду шодо дослідження предмета публічно-правового спору $[11$, с. 62].

Категорія «суб'єкт адміністративного судочинства», вважає зазначений науковець, $\epsilon$ ширшою за змістом, порівняно 3 категорією «учасник адміністративного судочинства». Суб' $€$ ктів адміністративного судочинства як осіб, що можуть набути та за наявності певних умов набувають правового статусу в адміністративних процесуальних відносинах, доцільно віднести до таких груп за ознакою виконуваних у судовому адміністративному процесі функцій: 1) адміністративний суд (власне суд, його посадова особа, 
колегія суддів); 2) сторони, треті особи; 3) представники; 4) органи й особи, яким закон надає право захищати права, свободи та інтереси інших осіб; 5) секретар судового засідання, судовий розпорядник, перекладач; 6) свідки; 7) експерт, спеціаліст [12, с. 42].

Учасником адміністративного судочинства (адміністративного судового процесу) є особа, яку чинним законодавством України наділено процесуальними правами й обов'язками у сфері розгляду адміністративних справ адміністративними судами та яка вступає до адміністративного процесу для захисту своїх прав і законних інтересів, захисту прав і законних інтересів інших осіб або з метою сприяння здійсненню адміністративного процесу, тобто це особа, яка може вчиняти процесуальні діï, спрямовані на досягнення мети процесу хоча б в одній зі стадій адміністративного процесу.

Важливою умовою одержання статусу учасника адміністративного процесу $є$ володіння особою такою ознакою, як алміністративна процесуальна правосуб'єктність. У дослідженнях, присвячених проблемам розвитку адміністративних процесуальних відносин (О.В. Кузьменко [10; 13], А.Т. Комзюк, В.М. Бевзенко, Р.С. Мельник [14], В.С. Стефанюк [15], Н.В. Александрова, Р.О. Куйбіда [16], М.М. Ясинюк [17] та інші), розкрито зміст процесуальних прав та обов'язків кожного учасника або групи учасників судового адміністративного процесу. При шьому відправною точкою для формування поняття суб' $€$ кта адміністративного процесу $є$ визначення поняття адміністративної прошесуальної правосуб' $є$ ктності.

Правосуб 'єктність як загальна категорія права вивчалася в теорії права. У процесі наукового аналізу обгрунтовувалися різні думки щодо сутності зазначеної категорії. Так, Ю.К. Толстой виходив із позиції про відсутність підстав розмежування понять правоздатності та правосуб'єктності [18, с. 19]. Пізніше О.В. Мицкевич було обгрунтовано необхідність розмежування зазначених понять $[19$, с. 106]. С.С. Алексєєв зазначав, що правосуб́єктність $€$ первинною ланкою конкретизації юријичних норм, у якій визначається загальне юридичне положення суб'єкта та відношення суб'єктів щодо один одного $[20$, с. 277,279$]$. У подальших роботах учений поглибив цей підхід, наголошуючи, що правосуб'єктність - це насамперед суб'єктивні права особи. Цим суб'єктивним правам кореспондуються юридичні обов'язки. Склад елементів галузевої правосуб'єктності відрізняється залежно від правової природи тих прав, врегулювання яких здійснюється нормами певної галузі права. Узагальнено правосуб'єктність проявляється через правоздатність, дієздатність і деліктоздатність [21, с. 380-381].

О.Ф. Скакун розглядає правосуб'єктність як самостійну правову категорію, шо існує поряд із правами й обов'язками. Вона свідчить про правову здатність особи бути носієм цих прав та обов'язків. Отже, правосуб'єктність $€$ не кількісним вираженням прав суб'єкта, а постійним громадянським станом особи, не володінням правами, а передумовою, здатністю здобувати та здійснювати суб'єктивні права. Виходячи з такого підходу, зазначено, що сама правосуб'єктність у всіх є однаковою, однак різною за змістом - набором суб́єктивних прав кожної особи. Момент переходу 
правосуб'єктності в суб'єктивне право учений пов'язує з появою юридичного факту $[22$, с. $535-536]$.

Не суперечить підходу шодо визнання правосуб'єктності передумовою здобуття та здійснення суб'єктивних прав також точка зору про те, шо правосуб'єктність $€$ однією з обов'язкових юридичних передумов правовідносин, можливістю чи здатністю особи бути суб'єктом права з усіма відповідними наслідками. При цьому виокремлено чотири елементи правосуб'єктності: 1) правоздатність, 2) дієздатність, 3) деліктоздатність як здатність відповідати за цивільні правопорушення (делікти), 4) осудність умова кримінальної відповідальноості [23, с. 444-445].

О.В. Кузьменко визначає адміністративно-процесуальну правоздатність як здатність мати юридичні права й обов'язки в адміністративному процесі. Вона визнається за всіма громадянами України, іноземцями, особами без громадянства, а також за органами державної влади, іншими державними органами, органами влади Автономної Республіки Крим, органами місцевого самоврядування, їх посадовими та службовими особами, підприємствами, установами, організаціями, які $є$ юридичними особами [24, c. $68-69]$.

Питання шодо адміністративної процесуальної дієздатності суб'єктів владних повноважень - органів публічної влади, органів влади APK, ix посадових і службових осіб, підприємств, установ, організацій вирішується, виходячи зі статусу колективного суб'єкта правовідносин, а також 3 урахуванням набуття особлливого статусу посадової особи.

Складовою процесуальної дієздатності $€$ адміністративно-процесуальна деліктоздатність, тобто здатність суб'єкта нести за порушення адміністративно-процесуальних норм юридичну відповідальність [24, с. 69]. Вона охоплюється категорією „ієздатності, а шодо суб'єктів адміністративного судочинства вирішується, виходячи з того, яку процесуальну роль вони виконують у провадженні.

Отже, серед учених-представників науки загальної теорії права й досі не сформовано єдиного підходу шодо визначення змісту правосуб'єктності. Серед найбільш поширених наукових думок щодо сутності категорії «правосуб'єктність» можна виокремити такі: 1) особливе суб'єктивне право, яке належить до складу загальних правовідносин; 2) передумова здобуття і здійснення суб'єктивних прав; 3) ототожнення з правоздатністю; 4) ототожнення з правовим статусом.

Для вивчення проблеми змісту адміністративної процесуальної правосуб'єктності найбільшу наукову цінність являє, як вбачається, науковий підхід, сформульований С.С. Алексєєвим, шодо визначення сутності правосуб'єктності, оскільки він $є$ загальним (тобто таким, що може бути застосований до будь-яких правовідносин: цивільних, адміністративних тощо), а також системним: його використання дозволить усебічно дослідити місце певного учасника процесуальних правовідносин у самому процесі. Виокремлений підхід дозволяє охарактеризувати зміст категорії адміністративної процесуальної правосуб'єктності, виходячи з особливостей 
відповідних правовідносин, правової природи тих прав, які виникають у сфері, що є предметом наукового аналізу [25, с. 134].

Як справедливо зазначає В.І. Бутенко, визначення змісту адміністративної процесуальної правосуб'єктності передбачає вирішення низки питань у такій логічній послідовності: по-перше, здійснення аналізу тих адміністративних відносин, суб'єкти яких набувають процесуальної правосуб'єктності; по-друге, здійснення характеристики правової природи прав, які виникають в адміністративній процесуальній сфері; по-третє, визначення структури адміністративної процесуальної правосуб'єктності, зокрема встановлення елементів, які до неї входять, і ї складу [26, с. 48].

Перший виокремлено на основі аналізу тих адміністративних відносин, суб'єкти яких набувають процесуальної правосуб'єктності. Такими постають відносини у сфері адміністративного процесу. Пунктом 5 ч. 1 ст. 3 КАС Украіни адміністративний процес визначено як правовілносини, що складаються під час здійснення адміністративного судочинства. Законодавчо встановлене поняття адміністративного процесу виводить його за межі теоретичного розуміння сутності адміністративного процесу, оскільки ними не передбачено відносин у сфері відправлення адміністративного судочинства. У монографіi «Адміністративна юстиція України: проблеми теорії і практики», опублікованою за редакцією О.М. Пасенюка, адміністративну юстицію визначено як судовий контроль за діяльністю органів виконавчої влаЈи та названо складовою частиною адміністративного процесу [2, с. 60]. Фактично аналогічний підхід підтримано О.В. Кузьменко та Т.О. Гуржій $[27$, с. 116].

Відносини, які складаються в адміністративних судах під час відправлення адміністративного судочинства (адміністративного процесу), принципово відрізняються від тих відносин, які складаються під час здійснення процесу управління чи юрисдикційної діяльності в управлінській сфері. Принципова різниця полягає. в тому, шо перший вид адміністративно-процесуальних відносин складається під час відправлення правосуддя спешіалізованими адміністративними судами, інші відносини з правосуддям не пов'язані, навіть у разі розгляду справ про алміністративні правопорушення судами загальної юрисдикції, проте стосуються процесу діяльності публічної адміністрації.

Адміністративний процес пропонується визначати як урегульовані нормами адміністративного процесуального права правовідносини, що виникають між адміністративним судом, сторонами та іншими учасниками адміністративної справи, з приводу розгляду та вирішення шим судом пуб́лічно-правових спорів, учасниками яких $\epsilon$, по-перше, суб'єкти державно-владних повноважень, по-друге, фізичні та юридичні особи [14, с. 45-53]. Досить поширеним є підхід щодо застосування терміна «судовий адміністративний процес» стосовно процесуального порядку відправлення правосуддя адміністративними судами. Така пропозиція висловлювалася В.С. Стефанюком [15, с. 82]. Авторським колективом підручника «Адміністративне право України: Академічний курс» доводилася доцільність використання терміна «адміністративно-судовий процес» [28, с. 492]. 
Як уявляється, ступінь теоретичного опрацювання адміністративного судочинства поряд із необхідністю перегляду предмета адміністративного права, на якому наголошують сучасні дослідники, ставить питання про остаточний перехід від широкого розуміння адміністративного процесу до суто судової концепції й відтак знімає необхідність використання терміна «адміністративний судовий процес».

Як зазначалося вище, ст. $48 \mathrm{KAC} \mathrm{України} \mathrm{визначено} \mathrm{зміст} \mathrm{адміністра-}$ тивної процесуальної правосуб'єктності як категорії, що містить адміністративну процесуальну правоздатність та адміністративну процесуальну дієздатність. Важливо звернути увагу на те, що фізичні особи завжди мають адміністративну процесуалььну правоздатність, проте реалізувати свої процесуальні права й обов'язки може не кожна фізична особа. Маються на увазі неповнолітні, фізичні особи, визнані судом недієздатними, які є сторонами чи третіми особами. Самостійно вони не можуть звертатися до адміністративного суду та брати участь у судовому адміністративному процесі. До досягнення повноліття фізичні особи можуть реалізувати свої процесуальні права й обов'язки в публлічно-правових спорах у випадках, коли законодавством ї наділено відповідними правами й обов'язками [29, с. 351-352]. Opгани державної влади, місцевого самоврядування, їхні посадові та службові особи, підприємства, установи, організаціі мають одночасно адміністративну процесуальну правоздатність та адміністративну процесуальну дієздатність, оскільки як учасники адміністративних процесуальних правовідносин вони можуть виступати тоді, коли є легітимованими.

Варто підтримати точку зору про те, що, крім загальної адміністративної процесуальної правоздатності, необхідно мати ще конкретну адміністративну процесуальну правоздатність, тобто правоздатність у конкретній адміністративній справі $[29$, с. 352]. Зумовлюе це положення судова практика з адміністративних справ. Зокрема, існують певні особ́ливості судового розгляду справ за участі органів державної податкової служби, коли необхідно визначати предмет спору та, відповідно, компетенцію щодо розгляду справи. Крім того, сам публічно-правовий спір, шо виникає з податкових відносин і прийняття рішення у відповідній адміністративній справі, залежать також від статусу конкретного органу державної податкової служби, його відповідної адміністративної процесуальної правосуб'єктності (наприклад, ухвала Вищого адміністративного суду України від 8 червня 2012 р. в справі про визнання протиправними дій і відшкодування моральної шкоди, ухвала Вишого адміністративного суду України від 6 вересня 2012 р. в справі про визнання недійсним податкового повідомлення-рішення [30]).

Адміністративною процесуальною правосуб'єктністю наділено також блок партій, блок місцевих організацій, ініціативну групу референдуму, громадську організацію, яка може й не мати статусу юридичної особи. Ці суб'єкти можуть бути учасниками правовідносин, пов'язаних із процесом виборів чи референдуму, вілповідно до законів, а також згідно зі ст. ст. $172,174,175 \mathrm{KAC}$ Україн, якими визначено особливості провадження в 
справах, пов'язаних із виборчим процесом чи процесом референдуму. У справах про тимчасову заборону окремих видів або всієї ціяльності, ліквідацію об'єднання громадян відповідачами можуть бути об'єднання громадян, у тому числі громадські організаціi $[29$, с. 353].

Таким чином, обсяг і характер адміністративної процесуальної правосуб'єктності осіб, які беруть участь у справі, позначається на їх процесуальному статусі. Склад елементів процесуального статусу осіб, які беруть участь у справі, доцільно доповнити законним інтересом, враховуючи наявність юридичної зацікавленості в розгляді адміністративної справи. Що стосується процесуального статусу інших учасників судового адміністративного процесу, то до його елементів доці.ьно віднести процесуальні права та обов'язки. Оскільки в інших учасників відсутній законний інтерес щодо результатів судового розгляду адміністративної справи, включати його як окремий елемент статусу недоцільно.

Разом із тим учасників адміністративного процесу, крім власних специфічних прав та обов'язків, наділено правоздатністю, яка однаковою мірою $\varepsilon$ характерною для всіх суб'єктів адміністративного процесу. Зокрема, особи, які беруть участь у справі, мають право знати про дату, час і місце судового розгляду справи, про всі судові рішення, які ухвалюються в справі та стосуються іхніх інтересів (ч. 3 ст. $49 \mathrm{KAC} \mathrm{Украйни).}$

Як було зазначено више, адміністративна процесуальна правоздатність учасників алміністративного процесу класифікується на два види: загальна й спеціальна. Спеціальна адміністративна процесуальнна правоздатність учасників адміністративного процесу - це права й обов'язки, які може мати лише одна конкретна особа, що бере участь у справі. Відтак можна говорити про існування правосуб'єктності сторін, третіх осіб, їх представників, секретаря судового засідання, судового розпорядника, свідка, експерта, спеціаліста, перекладача. Обсяг і зміст спеціальної правосуб'єктності залежать від процесуальних завдань та інтересів кожного учасника адміністративного процесу, а також стадіі процесу, на якій вона фактично реалізується.

Як було зазначено вище, шоб особисто брати участь у розгляді адміністративної справи, недостатньо володіти тільки адміністративною процесуальною правоздатністю. Необхідним для учасника справи $є$ також володіння адміністративною процесуальною дієздатністю. Адміністративна процесуальна дієздатність - це здатність особисто здійснювати свої адміністративні процесуальні права й обов'язки, у тому числі доручати ведення справи представникові. Вона належить фізичним особам, які, по-перше, досягли повноліття, а по-друге, не визнані судом недієздатними. Вона може належати також фізичним особам до досягнення повноліття в спорах із приводу публічно-правових відносин, у яких вони, відповідно до законодавства, можуть самостійно брати участь. Це, наприклад, можуть бути справи, у яких позивачем $є$ неповнолітній, а відповідачем $є$ адміністрація державного навчального закладу, яка відмовила неповнолітньому в прийманні в цей заклал або відрахувала його із закладу. Таким чином, у законодавстві відображено думку науковців про доцільність виокремлення 
категорій повної та часткової адміністративно-процесуальної дієздатності громадянина $[9$, с. 76$]$.

Відповідно до ч. 4 ст. 56 КАС України права, свободи та інтереси малолітніх і неповнолітніх осіб, які не досягли віку, з якого настає адміністративна процесуальна дієздатність, а також недієздатних фізичних осіб, захищають у суді їхні законні представники - батьки, усиновлювачі, опікуни, піклувалььнки чи інші особи, визначені законом. Це ж стосується прав, свобод та інтересів неповнолітніх осіб, які досягли віку, з якого настає адміністративна процесуальна дієздатність, непрацездатних фізичних осіб і фізичних осіб, цивільна дієздатність яких є обмеженою (ч. 5 ст. 56 КАС України).

Наявність адміністративної процесуальної правосуб'єктності дає змогу учасникам адміністративного процесу використовувати процесуальні права та обов'язки, закріплені в законодавстві, для досягнення тих цілей, шо стоять перед ними під час вступу в процес. Сукупність процесуальних прав та обов'язків учасників адміністративного судочинства визначають ї процесуальне становище та дають ім можливість відігравати активну роль в адміністративному процесі. Обсяг процесуальних прав та обов'язків учасників адміністративного судочинства залежить від їх цілей у процесі та належності до певної групи. Так, особи, які беруть участь у справі, наділені великим обсягом процесуальних прав, які вони здійснюють під час розгляду справи в ајміністративному суді. Наявність широкого кола й особливостей процесуальних прав у осіб, які беруть участь у справі, $\epsilon$ ще однією відмінністю цієї групи осіб від інших учасників адміністративного процесу. Особи, які беруть участь у справі, наділені також певними обов'язками, шо кореспонјують процесуальним правам інших осіб та дають змогу суду здійснювати ефективний розгляд адміністративної справи.

Процесуальні права й обов'язки осіб, які беруть участь у справі, не $\epsilon$ зовсім однаковими, проте рівність становиша цих осіб підтверджується тим, шо вони мають рівні процесуальні права й обов'язки. Таким чином, процесуальні права й обов'язки будь-якої особи, яка бере участь у справі, не можуть визнаватися більш або менш важливими, ніж права й обов'язки другої особи, яка бере участь у справі.

Адміністративний суд повинен надавати сприяння всім особам, які беруть участь у справі, у реалізації цих змагальних прав. Для цього він має роз'ясняти особам їні процесуальні права, попереджати про наслідки вчинення певних процесуальних дій тощо. Диспозитивні права - це встановлені в законі можливості особи, яка бере участь у справі, розпоряджатися своїми вимогами на свій розсуд. [31, с. 96]. До диспозитивних прав належить право оскаржувати судові рішення в частині, що стосується інтересів особи, яка бере участь у справі. Крім цього, до диспозитивних прав осіб, які беруть участь у справі, відносяться й інші, наприклад, позивач в адміністративному процесі має. право змінити підставу або предмет адміністративного позову, а відповідач має право визнати адміністративний позов повністю або частково. 
Розглядаючи питання про процесуальні права й обов'язки інших учасників адміністративного судочинства, варто зазначити, шо для них не встановлено універсального переліку таких прав та обов'язків. Стосовно кожного учасника адміністративного судочинства із пієї групи КАС Украіни встановлюе спешифічні процесуальні права та обов'язки, у яких повністю відображено функції, що виконують у процесі ці суб'єкти [32, с. 268]. Отже, з'ясувавши поняття, класифікацію та правосуб'єктність учасників адміністративного судочинства, треба визначити поняття та види сторін в адміністративному судовому процесі, а також најати загальне визначення ix адміністративно-процесуальної правосуб'єктності.

У провадженнях 3 адміністративного судочинства особами, які мають інтерес у справі, є громадяни, державні органи, органи місцевого самоврядування, державні службовші, організаціі, підприємства, установи, заклади незалежно від форм власності, які в адміністративному судочинстві прийнято називати сторонами.

Сторонами в адміністративному процесі $є$ позивач і відповідач. Стаття $50 \mathrm{KAC} \mathrm{України} \mathrm{закріплює,} \mathrm{що} \mathrm{в} \mathrm{судовому} \mathrm{процесі} \mathrm{можуть} \mathrm{бути,} \mathrm{з} \mathrm{одного}$ боку, особа, яка вважає, шо ії право, свободи чи правовий інтерес у сфері публічно-правових відносин порушено, і звертається до адміністративного суду за захистом цього права, свобод чи правового інтересу, а з іншого особа, яка, як вважає позивач, порушила його право, свободу чи правовий інтерес і повинна усунути ше порушення (відповідач) [33, с. 53]. Отже, сторонами в адміністративному процесі $є$ особи, які беруть участь у справі від свого імені та з метою захисту своїх власних прав та інтересів, спір між якими про їх суб'єктивні права й обов'язки має бути вирішений судом.

Отже, сторонами в адміністративному судочинстві $€$ позивач і відповідач як можливі учасники оспорюваних прав та обов'язків, шо є суб'єктами публічно-правових відносин. Вони $є$ головними учасниками, без яких неможливий сам прошес.

Характерною ознакою сторін $\epsilon$ те, шо вони мають право звертатися до суду за захистом і навіть тоді, коли особи лише вважають, шо іхні права, свободи та інтереси у сфері публічно-правових відносин порушено, хоча таке порушення, можливо, і не мало місця насправді. Суд повинен розглянути такий спір тому, що, крім конституційної гарантії права (ст. 55), на оскарження в суді рішень, дій чи бездіяльності органів державної влади, органів місцевого самоврядування, посадових і службових осіб, ч. 2 ст. 6 КАСУ встановлюється, шо ніхто не може бути позбавлений права на розгляд його справи в адміністративному суді.

Наступною ознакою сторін $€$ також те, шо у всіх випадках прошес в адміністративній справі ведеться від імені та в інтересах сторін. Це правило діє також, коли справу порушує не особисто позивач, а інші особи в його інтересах. Позивач - це особа, на захист прав, свобод та інтересів якої подано адміністративний позов до адміністративного суду. Позивачем в адміністративній справі можуть бути громадяни України, іноземці чи особи без громадянства, підприємства, установи, організації (юридичні особи). 
Позивачем може бути також суб'єкт владних повноважень у випадках, коли позовна заява до адміністративного суду подається на забезпечення виконання його повноважень. Відповідач - це суб'єкт владних повноважень, якшо інше не встановлено КАС України.

Громадяни України, іноземці чи особи без громадянства, їх об'єднання, юридичні особи, які не $\epsilon$ суб'єктами владних повноважень, можуть бути відповідачами, відповідно до ч. 4 ст. 50 КАСУ, лише за адміністративним позовом суб'єкта владних повноважень:

Сторони користуються рівними загальними процесуальними правами, обсяг яких збігається з правами й обов'язками інших осіб, які беруть участь у справі (ст. $49 \mathrm{KAC} \mathrm{України).} \mathrm{Враховуючи,} \mathrm{шо} \mathrm{сторони} \mathrm{займають}$ головне місце в розгляді справи, законодавець наділяе їх додатковими досить важливими процесуальними правами (ст. $51 \mathrm{KAC} \mathrm{України),} \mathrm{за} \mathrm{допо-}$ могою яких сторони можуть впливати на хіл справи.

Правове становище сторін в адміністративному судочинстві характеризується такими ознаками та особливостями:

- по-перше, сторони ведуть процес від власного імені, на їх ім'я виноситься та повною мірою поширюється сила судового рішення. На підставі принципу диспозитивності адміністративного процесуального права, звернення до суду за захистом своїх порушених чи оспорюваних прав прерогатива винятково заінтересованої особи (позивача) або особи, яка уповноважена пред'являти позови в інтересах інших осіб або держави (прокурором). Судове рішення як акт правосуддя виноситься стосовно прав та обов'язків конкретних сторін індивідуалізованого спірного правовідношення. Сторона веде процес від свого власного імені, відстоюючи порушені права, свободи чи інтереси. Участь у процесі сторони забезпечується зав дяки представництву іiі інтересів процесуальним представником. Повноваження представника, який бере участь в адміністративному процесі на основі договору, на здійснення представництва в суді мають бути підтверджені довіреністю чи усною заявою довірителя із занесенням ii до журналу судового засідання (ст. $58 \mathrm{KAC} \mathrm{України).} \mathrm{Необхідно,} \mathrm{щоб}$ у документі, який підтверджує повноваження представника, було чітко зазначено, якими саме правами наділяе представника сторона. У разі реалізації представником незакріпленої в довіреності чи іншому документі, який підтверджує повноваження представника, процесуальної дії, остання не може вважатися вчиненою стороною;

- по-друге, на сторін поширюються судові витрати. Пред'являючи позов до суду, позивач повинен сплатити передбачену законодавством суму судового збору. За наслідками розгляду справи одна зі сторін компенсує іншій стороні понесені витрати, пов'язані зі здійсненням судочинства (прибуття в судове засідання, залучення перекладача, експерта, прибуття свідків тощо). Водночас варто врахувати, що ця ознака в адміністративному судочинстві втрачає своє значення, оскільки в більшості випадків судові витрати компенсуються з відповідних бюджетів. Крім того, щодо значної кількості спорів не передбачено сплату судового збору; 
- по-третє, у разі вибуття або заміни сторони чи третьої особи у відносинах, шодо яких виник спір, суд допускає на будь-якій стадії адміністративного процесу заміну відповідної сторони чи третьої особи ії правонаступником. Усі діï, вчинені в процесі до вступу правонаступника, $\epsilon$ обов'язковими для нього такою самою мірою, якою вони були б обов'язковими для особи, яку він замінив;

- по-четверте, обов'язковою ознакою є юридична заінтересованість сторін. Так, у ст. 117 КАС України зазначається, що адміністративний суд порушує справи за позовними заявами суб'єктів, які звертаються до адміністративного суду за захистом прав, свобод та інтересів у сфері публічно-правових спорів. Однак на питання про те, у чому полягає цей інтерес, законодавство прямої відповіді не дає. Характерною рисою заінтересованості сторін $\in$ те, шо існування видів юридичної заінтересованості (матеріально-правової та прошесуально-правової) для позивача та відповідача полягає в нерозривній єдності.

Юридичну заінтересованість в адміністративному процесі має не лише позивач, для якого вона полягає в отриманні того б́лага, яке принесе йому рішення адміністративного суду про задоволення позову (матеріально-правовий інтерес), та у винесенні відповідного рішення про задоволення позову (процесуальний інтерес) [31, с. 77]. Так само юридичну заінтересованість, проте протилежну за змістом, має відповідач, для якого матеріально-правовий інтерес полягає у встановленні рішенням адміністративного суду відсутності будь-яких правових обов'язків перед позивачем, а процесуальний - у винесенні рішення про відмову в позові.

Таким чином, чинне законодавство розрізняє: 1) заінтересованих осіб, які звертаються до адміністративного суду за захистом своїх порушених прав та охоронюваних законом інтересів; 2) державні та інші органи, які звертаються до адміністративного суду у випадках, передбачених законодавчими актами України. Здійснивши таке розмежування, КАС України в подальшому не вважає державні та інші органи самостійними учасниками адміністративного процесу й форм їх участі не визначає, розглядаючи ї як позивачів [34, с. 68].

Відповідачем є особа, до якої звернено позивачем через суд позовні вимоги та яка, на думку позивача, має доповідати за позовною заявою.

Права та обов'язки сторін передбачені ст. 9 КАС України. Зазначеними в указаній нормі правами та обов'язками позивач і відповідач можуть користуватися на всіх стадіях адміністративного процесу. Однак деякі з них закріплено також в інших нормах КАС України. Так, ст. 51 п. п. 1, 2 KAC України передбачає можливість позивача змінити підставу або предмет позову, збільшити або зменшити розмір позовних вимог або відмовитися від адміністративного позову в будь-який час до завершення судового розгляду. Відповідач має право визнати позовні вимоги повністю або частково, подати заперечення проти адміністративного позову.

За допомогою реалізації права на подання позовної заяви особа стає стороною в адміністративному судочинстві. Виходячи із цього, право на 
звернення за судовим захистом і право особи на позов не варто розглядати як рівнозначні суб'єктивні права, тому що право на звернення до суду - загальне право, а право на позов - це певна конкретизація вказаного права.

Невирішеним $є$ питання шодо мети, яку переслідує особа під час пред'явлення позову. Із цього приводу Є.Г. Пушкар зазначав, що переслідуються цілі звернення за судовим захистом і залучення винних осіб до відповідальності за правопорушення, а також встановлення фактів та обставин, шо мають значення для здійснення суб'єктивних прав [35, с. 12]. О.О. Добровольський і С.О. Іванова у зв'язку із цим зазначають, що в конкретному процесі єдине право на позов реалізується, з одного боку, як право на порушення процесу, а з іншого - як право на позитивний результат процесу, тобто на одержання судового захисту порушеного чи оскарженого права [31, с. 92].

Відповідно до ст. 51 КАС України, крім прав та обов'язків, визначених у ст. $49 \mathrm{KAC}$ України, позивач має право змінити підставу або предмет адміністративного позову, збільшити або зменшити суми позовних вимог або відмовитися від адміністративного позову в будь-який час до закінчення судового розгляду. Позивач має право відмовитися від адміністративного позову також у суді апеляційної чи касаційної інстанції до закінчення, відповідно, апеляційного або касаційного розгляду. Це означає, шо в зазначеній нормі йдеться про комплекс прошесуальних прав, які в теорії адміністративного судочинства, на відміну від прав, закріплених ст. 49 КАС України, іменуються спеціальними правами, тому що ці права можуть здійснювати тільки позивач, відповідач, а також третя особа iз самостійними вимогами шодо предмета спору. Позивач, пред'явивши адміністративний позов до відповідача, має суб'єктивне право відмовитися від позову повністю або частково, шо також $є$ принципом диспозитивності адміністративного процесуального права. Зазначеним правом володіють і треті особи, шо висувають самостійні вимоги шодо предмета спору, оскільки мають стосовно останнього самостійний матеріально-правовий інтерес.

Відмова від адміністративного позову є єдиним поняттям адміністративного процесуального права та включає одночасно як відмову від суб'єктивних матеріальних прав, так і прагнення до ліквідації процесу за цим публічно-правовим спором. Відмова від позову $є$ недійсною за відсутності прямого волевиявлення позивача, необхідного для того, щоб воля позивача могла бути розпізнана для інших, а головне - для суду, і шоб відмова могла зумовлювати правові наслідки: припинення провадження в справі. Недійсною $\epsilon$ й відмова від позову, шо відбулася в результаті омани позивача та під впливом погроз і насилтьства $[36$, с. 36$]$

У той же час, як розглянуті права є правами, під час здійснення яких сторони розпоряджаються низкою суб'єктивних прав, спрямованих на зміну чи припинення процесу, варто визнати справедливим положення законодавства про те, що адміністративний суд не приймає відмови від позову, зменшення розміру позовних вимог, визнання позову відповідачем, якшо 
ці діï суперечать закону або порушують чиїсь права, свободи або інтереси (cт. $51 \mathrm{KAC}$ ).

Натомість зазначена позиція не $є$ пануючою. На думку деяких авторів, законодавство не повинно ставити за обов'язок суду перевіряти причини реалізації сторонами суб'єктивних прав, спрямованих на зміну чи припинення процесу, що ставляться в залежність від волевиявлення сторін $[37$, c. 36$]$.

Враховуючи, що для забезпечення виконання своїх процесуальних функцій сторони в адміністративному процесі наділені великим обсягом процесуальних прав та обов'язків, а також те, що сторони мають рівні процесуальні права й обов'язки, інакше кажучи, їм надано рівні можливості щодо відстоювання своєї позиції під час розгляду ајміністративної справи, iх віднесено законодавшем до групи осіб, які беруть участь у справі. Це передусім означає, шо вони володіють такими самими правами й мають ті ж обов'язки, що й особи, які беруть участь у справі. Проте сторони, зокрема позивач, займають головне місце в розгляді справи. Тому вони наділяються додатковими, надто важливими, процесуальними правами. Завдяки цим процесуальним правам позивач суттєво впливає на процес справи з огляду на диспозитивні права, перераховані в п. 1 ст. 51 КАС України $[38$, с. 81$]$.

Таким чином, залежно від суспільно-державної ролі сторони (позивач та відповідач) адміністративного процесу поділяються на суб'єктів владних повноважень, фізичних і юридичних осіб. Конституційна гарантія судового захисту законних прав і свобод людини та громадянина (ст. ст. 8, 55 Конституції України) набула подальшого розвитку в нормах Закону України «Про судоустрій і статус суддів» і КАС України. Зокрема, ст. 2 вказаного закону закріплено, шо завданням адміністративного судочинства $€$ захист прав, свобод та інтересів фізичних і юридичних осіб у сфері публічно-правових відносин від порушень із боку органів державної влади, органів місцевого самоврядування, їх посадових і службових осіб, інших суб'єктів під. час здійснення ними владних управлінських функшій на основі законодавства, у тому числі на виконання делегованих повноважень.

3 викладеного постає, що національним процесуальним законодавством урегульовано не лише безпосередню реалізацію конституційного права фізичних $\mathrm{i}$ юридичних осіб на судовий захист, а й визначено суб'єкта правовідносин, який поряд із фізичними та юридичними особами $є$ одним з основних учасників адміністративного судочинства, тобто в порядку адміністративного судочинства передбачено можливість оскарження рішень, дій чи бездіяльності суб̆'єкта владних повноважень (ч. ч. 2,3 ст. 2 КАС України).

Поняття «суб̆'єкт владних повноважень», уперше закріплене КАС України, не отримало належного й вичерпного обгрунтування в адміністративно-правовій науці та національному законодавстві, а тому необхідно висвітлити сутність цього поняття та характерні ознаки таких суб'єктів. Отже, суб'єкт владних повноважень - це уповноважений державою суб'єкт (орган, підприємство, установа, організація, посадова чи службова особа), який на основі та відповідно до чинного законодавства здійснює 
управлінський чи регулятивний вплив як на суспільство в цілому, так і на його окремі елементи (групи, інститути тошо) [39, с. 103].

На відміну від суб'єктів владних повноважень, які здійснюють державні функціï, фізичні та юридичні особи вступають в адміністративний процес для забезпечення власних матеріально- та процесуально-правових інтересів. Термін «фізична особа» $є$ узагальнюючим та охоплює такі поняття, як «громадянин України», «іноземець» та «особа без громадянства», які отримали закріплення в національному законодавстві. Поняття «юридична особа» та його зміст визначено в Цивільному кодексі України, згідно зі ст. 80 якого юридична особа - організація, створена й зареєстрована у встановленому законом порядку [40].

Розпочинаючи аналіз статусу сторін в алміністративному процесі, треб́ визначити, шо $є$ характерним для їх процесуальних прав та обов'язків. Так, суб'єктивні права сторін в алміністративному процесі можуть бути охарактеризовані такими особливостями: 1) суб́'єктивні права - це можливість певної поведінки; 2) ця можливість надана особі, яка володіє адміністративною процесуальною правоздатністю й адміністративною процесуальною дієздатністю; 3) ця можливість надана з такою метою: а) для захисту законних прав, свобод та інтересів суб'єкта, який перебуває в правовідносинах з органами державної влади або органами місцевого самоврядування; б) для вирішення в судовому порядку публічно-правових спорів, які виникають із таких правовідносин; 4) поведінка сторін адміністративного процесу реалізується в адміністративних процесуальних правовідносинах; 5) поведінка сторін адміністративного процесу $є$ нормативно обмеженою, а порушення цих меж (міри можливої поведінки) визнається зловживанням правом; 6) процесуальні права сторін існують тільки у зв'язку з наявністю відповідних юридичних обов'язків з боку іншого учасника правові.носин і без виконання цих обов'язків не можуть бути реалізованими; 7) реалізація прав гарантується державним примусом або осудом щодо носія кореспондуючого обов'язку; 8) процесуальні права сторін мають юридичну природу, оскільки надаються адміністративними процесуальними нормами й гарантуються державою.

Тому під правами сторін в адміністративному процесі можна розуміти надану й гарантовану процесуальним законодавством свободу обирати вид поведінки, яка впливатиме на інших учасників адміністративних процесуальних правовідносин із метою забезпечення процесуальних інтересів позивача та відповідача за конкретною адміністративною справою.

Категорією, шо кореспондує суб'єктивним правам в алміністративному прошесі, $\epsilon$ суб'єктивні юридичні обов'язки сторін. Характерними особливостями обов'язків сторін в адміністративному судочинстві $€$ такі: а) становлять необхідну, належну поведінку; б) можуть покладатися тільки на дієздатну особу; в) покладаються в інтересах інших осіб; г) такі обов'язки реалізуються в адміністративних процесуальних правовідносинах; д) не можуть існувати поза зв'язками із суб'сктивними правами інших учасників правовідносин в адміністративному процесі; е) реалізація таких обов'язків забезпечується державним примусом або осудом; ж) мають нормативно встановлені межі; 
3) вони мають юридичну природу, оскільки закріплені адміністративними процесуальними нормами й гарантуються державою.

Таким чином, у цьому випадку під обов'язком сторони в адміністративному процесі треба розуміти установлену державою та забезпечену нормами права його належну поведінку, якої необхідно дотримуватися під час розгляду та вирішення адміністративного публічно-правового спору.

Разом із тим суб' $є$ ктивні права й обов'язки мають як спільні ознаки, так і ознаки, що дозволяють їх розмежовувати. Об'єднує їх спільна адміністративно-процесуальна природа, існування в адміністративних процесуальних правовідносинах, наявність меж у поведінці (те й інше $є$ мірою), належність особам, які мають адміністративну процесуальну правоздатність та алміністративну процесуальну дієздатність, наявність державних гарантій. Відмінності полягають у тому, шо: а) права реалізуються в інтересах їх носія, а обов'язки - в інтересах інших осіб; б) права - це міра можливої, а не необхідної поведінки.

Отже, процесуальний статус сторін в адміністративному процесі треба розглядати як закріплені процесуальним законодавством власні правові можливості та зобов'язання діяти відповідним чином шојо інших учасників такого процесу, адміністративного суду для досягнення дозволеної законом процесуальної мети, захисту, відновлення суб'єктивних прав, свобод та інтересів.

Безпосередньо називаючи права та обов'язки сторін у судовому процесі, варто зазначити, шо вони можуть бути класифікованими на види за різними критеріями. Так, залежно від правового статусу права й обов'язки сторін поділяються на загальні та спеціальні. Загальні права й обов'язки сторін це права й обов'язки, які передбачаються не лише для сторін, а й поширюються на інших учасників адміністративного процесу. Цей вид повноважень закріплений, зокрема, у ст. $49 \mathrm{KAC}$ України. Загальні повноваження можуть бути використані та мають дотримуватися сторонами адміністративного процесу протягом усього розгляду та перегляду алміністративної справи, включно до останньої стадії адміністративного процесу.

Відповідно до цієї норми особи, які беруть участь у справі, мають рівні процесуальні права й обов'язки. Таким чином, законодавець гарантує всім учасникам адміністративної справи однакові можливості для здійснення своїх інтересів в адміністративному процесі. Крім того, у цьому випадку проявляється дія принципу рівності всіх учасників адміністративного процесу перед законом і судом.

Права осіб, які беруть участь у справі, забезпечують їм можливість бути безпосереднім учасником судового розгляду справи, здійснювати процесуальні діiі, спрямовані на обгрунтування їхньої процесуальної позиції, доводити обгрунтованість своїх вимог і заперечень, захищати власні суб'єктивні інтереси. Так, особи, які беруть участь у справі, мають право знати про дату, час і місце судового розгляду справи, про всі судові рішення, які ухвалюються в справі та стосуються їхніх інтересів; знайомитися з матеріалами справи; заявляти ктопотання й відводи; давати усні та письмові пояснення, доводи та заперечення; подавати докази, брати участь у дослідженні доказів; висловлювати свою дум- 
ку з питань, які виникають піп час розгляду справи; ставити питання іншим особам, які беруть участь у справі, свідкам, експертам, спеціалістам, перекладачам; подавати заперечення проти клопотань, доводів і міркувань інших осіб; знайомитися з технічним записом і журналом судового засідання та подавати писымові зауваження до них; робити з матеріалів справи виписки, знімати копії з матеріалів справи, одержувати копіі судових рішень; оскаржувати судові рішення в частині, що стосується іхніх інтересів; користуватися іншими процесуальними правами, наданими їм КАС України. Крім того, особи, які беруть участь у справі, можуть за власний рахунок додатково замовити та отримати в суді засвідчені копіі документів і витяги з них (ч. 2 ст. 119 КАС України).

На вілміну від прав, обсяг яких є досить значним, обов'язки сторін, як i для решти учасників ајміністративного прошесу, полягають у такому: сторони зобов'язані добросовісно користуватися належними ім процесуальними правами; сторони зобов'язані неухильно виконувати процесуальні обов'язки; кожна сторона повинна довести ті обставини, на яких грунтуються ї вимоги та заперечення.

Суд може постановити ухвалу про обов'язковість особистої участі сторін чи третіх осіб у судовому засіданні. Викликати сторону чи третю особу для особистих пояснень можна й тоді, коли в судовому розгляді беруть участь ї представники (ч. 1 ст. $120 \mathrm{KAC} \mathrm{України).}$

Спеціальні права й обов'язки притаманні винятково сторонам адміністративного процесу. Як правило, вони не можуть здійснюватись іншими учасниками адміністративного процесу. Отже, крім загальних прав та обов'язків, визначених ст. 49 КАС України, сторони одночасно користуються власними правами, закріпленими в ст. 51 КАС України.

Однак повноваженнями сторін в адміністративному процесі можуть наділятися такі його учасники, як процесуальні представники та треті особи. Перші здійснюють процесуальні дії в інтересах та від імені сторін, а відтак, представляючи позивача чи відповідача, тимчасово виконують за нього процесуальні дiі, спрямовані на постановлення судом позитивного рішення в справі. Відповідно, пропесуальні представники мають користуватися повноваженнями осіб, яких представляють.

Оскільки в адміністративному процесуальному законодавстві закріплено, що треті особи мають власну зацікавленість щодо предмета спору (ст. 53 КАС України), претендують на постановлення рішення суду, яким задовольнялися б ї претензіі шодо такого предмета, то, відповідно, вони також визнаються носіями повноважень сторін адміністративного процесу (ст. 54 КАС України).

Завдяки спеціальним правам, закріпленим у ст. 51 КАС України, сторони в адміністративному процесі, на відміну від інших учасників, можуть ві.тьно розпоряджатися предметом адміністративного позову, захищати свої матеріальні та процесуальні інтереси в судах вищих інстанцій. Однак важливим $\epsilon$ те, що права й обов'язки сторін, згідно з положеннями цієї статті, не $є$ оЈнаковими, вони поділяються залежно від процесуального статусу окремої сторони адміністративного процесу. Так, позивач має право: 1) змінити 
підставу або предмет адміністративного позову; 2) збільшити або зменшити розмір позовних вимог; 3) відмовитися від адміністративного позову в будьякий час до закінчення судового розгляду, у тому числі й у суді апеляційної чи касаційної інстанції до закінчення, відповідно, апеляційного чи касаційного розгляду. Відповідач має право: 1) визнати ајміністративний позов повністю або частково; 2) подати заперечення проти адміністративного позову.

Попри наявність у сторін власних специфічних прав, вони можуть здійснювати права, спільні і для позивача, і для відповідача. Так, сторони можуть досягти примирення на будь-якій стадії адміністративного процесу, що є підставою для закриття провадження в адміністративній справі (ч. 3 ст. 51 КАС України). Види й склад прав та обов'язків сторін залежить також від процесуальної стадії, яка в конкретний момент часу відбувається у зв'язку з розглядом і вирішенням публліно-правового спору Так, сторін адміністративного процесу наділено такими правами й обов'язками: 1) у суді першої інстанції: а) у зв'язку з порушенням адміністративної справи та їі підготовкою до судового розгляду (ст. ст. 112, 113 КАС України); б) у зв'язку із судовим розглядом адміністративної справи та прийняттям за нею остаточного рішення (ст.ст. 49, 51, 136, 137 КАС України); 2) у суді апеляційної інстанції (ст. ст. 185, 192, 193, 194 КАС України); 3) у суді касашійної інстаншії (ст. ст. 211, 217, 218, 219 КАС України); 4) у провадженні за винятковими обставинами (ст. ст. $236 \mathrm{KAC} \mathrm{Украї-}$ ни); 5) у провадженні за нововиявленими обставинами (ст. ст. 246, 251 KAC України); 6) щодо примусового виконання судових рішень (ст. 262 КАC України); 7) щодо відновлення втраченого провадження (ст. 269-1 КАС України).

За цільовою спрямованістю права й обов'язки сторін адміністративного процесу поділяються на такі види: 1) пов'язані з розвитком адміністративного процесу: права й обов'язки шодо порушення адміністративної справи та підготовки їі до судового розгляду (ст. ст. 104, 113, 119 КАС України), права й обов'язки шодо оскарження ухвал і постанов адміністративного суду (ст. ст. 185, 211, 236 КАС України); 2) спрямовані на припинення адміністративного процесу: права й обов'язки щодо укладення мирової угоди (ст. ст. 51, 113, 136, 194, 219, 262 КАС України).

Наведені види прав та обов'язків сторін адміністративного процесу не $\epsilon$ вичерпними. Свого часу Д.М. Чечотом було запропоновано таку класифікацію процесуальних прав сторін: а) права шодо порушення справи; б) права шодо відмови від позову; в) права шодо визнання позову; г) права шодо укладання мирової угоди; д) права на визначення обсягу судового захисту; е) інші прошесуальні права сторін [40, с. 307]. Права й обов'язки сторін в адміністративному процесі $є$ невід'ємними правовими категоріями, які нерозривно пов'язані з конкретним учасником адміністративного процесу. Сторони як обов'язкові головні й первинні учасники позовного провадження не можуть бути обмеженими в процесуальних правах або позбавлені їх. Водночас ускладнюються суспільні відносини у сфері публічного управління, розвивається адміністративний процес, розширюєть- 
ся сфера, шо може стати предметом судового розгляду, запроваджуються нові форми й види провајжень, які, відповідно, характеризуються особливостями статусу сторін, шо беруть у них участь.

\section{Література}

1. Дмитриев И.Л. Введение в общую теорию конфликтов / Л.И. Дмитриев, В.Н. Кудрявцев, Н.В. Кудрявцев. - М. : Центр конфлиттол. исслед., 1993. - 434 С.

2. Адміністратиена юстиція України: проблеми теорії і практики / [О.М. Пасенюк, О.Н. Панченко, В.Б. Авер'янов та ін. ; за заг. ред. О.М. Пасенюка. - К. : Істина, 2007. - 608 с.

3. Юрнднческая конфликтологня / О.В. Бойков, Н.В. Варламова, Н.Б. Пахоленко н др. - М. : Центр конфиктол. исслед., 1995. - 664 с.

4. Кудрявцев В.Н. Кридическая гонфликтология / В.Н. Кудрявцев / / Вестник РАН. - 1997. T. $67 .-$ Jo. 2 . - C. $124-128$.

5. Социологня права: Іучебное пособиеl / под ред. В.М. Сырых. - М. : Юрнд. дом «Юстицинфформ», 2001. $-420 \mathrm{c}$.

6. Тнхомнров К.А. Публичное право: |учебник]/ Ю.А. Тнхомиров. - М. : БЕК, 1995. $490 \mathrm{c.}$

7. Осадчнй А.Ю. Предмет судової адміністратнвної юрнсднкції / А.Ю. Осадчий / / Юрндичний вісник. - 2011. - ⿺ㅡ 2. - С. 114-118.

8. Кодекс адміністратнвного судочинства Українн : Закон Українн від 6 липня 2005 р. // Відомості Верховної Ради У країни. - 2005. - ło 35-37. - Ст. 44.

9. Адміністратнвне процесуальне (судове) право Vкраїнн : |підручннк| / за заг. ред. С.В. Ківалова. - О. : Юридична література, 2007. - 312 с.

10. Кузьменко О.В. Теоретичні засади адміністратнвного процесу : |монограффіяl / O.В. Кузьменко. - K. : Атіка, 2005. - $352 \mathrm{c}$.

11. Бачун О.В. Правовнй статус суб̆'сктів адміністратнвного судочинства : дис. ... канд. юрнд. наук : спец. 12.00.07 «Адміністративне право і процес: фінансове право: інформаційне право» / O.В. Бачун; Інститут законодавства Верховної Ради України. - K., 2010. - $206 \mathrm{c}$

12. Бачун О.В. До визначення категорії «суб'єКТ адміністративного судочинства» при розгляді справ адміністратнвннмн судамн / О.В. Бачун / / Вісник Верховного суду України. - 2009. No $6(106)$ - C. $38-43$

13. Кузьменко О.В. Адміністратнвна юстиція в Україні : |навчальний посібник] / O.В. Кузьменко. - K. : Атіка, 2007. - 156 c.

14. Комзюк А.Т. Адміністративний процес України : |навчальний посібник| / А.T. Комзюк, В.М. Бевзенко, Р.С. Мельник. - К. : Прецедент, 2007. - 531 с.

15. Стефанюк B.C. Судовнй адміністратнвний процес : [монограффія] / В.С. Стефанюк. - Х. : Консум, 2003. - 464 с.

16. Основи адміністратнвного судочннства та адміністратнвного права: [навчальний посібник] / за заг. ред. Р.О. Куйбіди, В.І. Шишкіна. - К. : Старий світ, 2006. - 256 с.

17. Толстой Ю.К. К теорни правоотношения / Ю.К. Толстой. - Л. : Изд-во Ленинград. ун-та, 1959. -86 c.

18. Мнцкевич А.В. Субъекты советского права / А.В. Мицкевнч. - М. : Госюриздат, 1962. $211 \mathrm{c.}$

19. Aлексеев С.С. Проблемы теорни права : у 2 т. / С.С. Алексеев. - Свердловск, 1972- . T. 1. $-1972 .-396 \mathrm{c}$

20. Алексеев C.С. Обшая теорня права: [учебник] / С.С. Алексеев. - 2-е нзд., перераб. н доп. М. : Велби: Проспект, 2008. $-576 \mathrm{c}$

21. Скакун О.Ф. Теория государства н права (энциклопедическнй курс) : [учебник] / О.Ф. Скакун. - Х. : Эспада, 2007. - $840 \mathrm{c}$.

22. Теорія державн і права: академічннй курс : |підручннк| / за ред. О.В. Зайчука, Н.М. Оніщенко. - К. : Крінком Інтер, 2006. - $688 \mathrm{c}$.

23. Кузьменко О.В. Курс адміністративного процесу: [навчальннй посібник]/ О.В. Кузьменко. K. : Юрінком Інтер, 2012. - 208 c.

24. Діткевнч І.І. Поняття «адміністратнвна процесуальна правосуб'єктність»: проблемн дефініції / I.1. Діткевич // Право і безпека. - 2010. - No 4(36). - C. 131-137.

25. Бутенко B.I. Структура адміністративної процесуальної правосуб'єктності / В.I. Бутенко / / Наше право. - 2008. - No 4. - 4. 2. - C. $48-52$. 
26. Кузьменко О.В. Адміністративно-процесуальне право України : [підручник」/ [О.В. Кузьменко, Т.О. Гуржій] ; за ред. О.В. Кузьменко. - К. : Атіка, 2007. - 416 с.

27. Адміністративне право Україн: академічний курс : [підручник] : у 2 т. / ред. кол. : В.Б. Авер'янов (голова) та ін. - К. : Крнднчна думка, 2007- . - Т. 1 : Загальна частина. 2007. - 592 c.

28. Кодекс адміністратнвного судочннства Українн: науково-практнчннй коментар : у 2 т. / [В.K. Матвійчук, I.О. Хар] : за заг. ред. В.К. Матвійчула. - К. : KHT, 2007- . - Т. 1. 2007. $-788 \mathrm{c}$.

29. Судова практика Вищого адміністративного суду України (2011-2012рр.) / за заг. ред. Т.X. Темкіжева: Внший адміністратнвний суд Українн. - К. : Крінком Тнтер, 2012. - 272 с.

30. Добровольский А.А. Основные проблемы исковой формы защиты права / А.А. Добровольскнй, С.А. Иванова. - М. : Изд-во Моск. ун-та, 1979. - $158 \mathrm{c.}$

31. Топор I.В. Поняття та види учасників адміністративного судочинства: проблеми теорії / I.В. Tопор / / Актуа.льні проб̆лемн держави і права: зб. наук. праць. - 2011. - Вип. 58. C. 264-271.

32. Кодекс адміністративного судочинства Українн. Науково-практнчний коментар / |C.В. Ківалов, О.І. Харитонова, О.М. Аракелян та ін.] ; за ред. С.В. Ківалова, О.І. Харитонової ; OНЮА. - 3-є внд. - Х. : Одіссей, 2008. - $560 \mathrm{c}$.

33. Осокина Г.Л. О праве суда выйти за пределы исковых требований / Г.Л. Осокина // Росснйская юстнцня. - 1998. - № 6. - С. 48-54.

34. Пушкар Е.Г. Право на обрашение в суд на судебной зашитой : дисс. ... докт. юрид. наук : спец. 12.00 .03 «Гражданское право; семейное право; гражданскнй процесс; международное частное право» Е.Г. Пушкар ; Львовский национальный университет имени Ивана Франко. - Львов, $1983 .-334 \mathrm{c}$.

35. Елисейкин П.Ф. Изменение предмета и основания иска / П.Ф. Елисейкин // Советская юстнция. - 1969. - № 5. - С. $35-38$

36. Шевчул П.І. Проблеми судово-правової реформи / П.І. Шевчук, В.В. Кривенко. Г.А. Ярема // Вісник Верховного Суду України. - 1997. - № 1. - С. 36-39.

37. Бречко А.В. Особливості правового положення сторін в адміністративному судочинстві / A.В. Бречко // Форум права. - 2009. - No 1. - С. 78-82. - [Електронний ресурс]. Режим доступу : http:/ / www.nbuv.gov.ua/e-journals/FP/2009-1/09bavvac.pdf.

38. Бевзенко В.М. Огляд адміністратнвного процесу й практикн його застосування / В.M. Бевзенко // Вісник вищого адміністративного суду в Україні. - 2011. - № 1. - С. 24-33.

39. Цивільний кодекс Українн: Закон України від 16 січня 2003 р. № 435-IV // Відомості Верховної Ради України. - 2003. - № 40-44. - Ст. 356.

40. Чечот Д.М. Участннки гражданского процесса / Д.М. Чечот / Избранные труды по гражданскому процессу. - СПб. : Изд. Дом гос. ун-та, 2005. - 616 с.

\section{Анот а ч я}

Kisasos C. B. Понятійно-правова характеристика сторін як учасників адміністративного судочинства. - Стаття.

У статті проаналізовано поняття, сутність і види учасників адміністративного судочинства та місце сторін у ї системі. Особливу увагу приділено співвідношенню понять «учасник адміністративного судочинства» та "суб'скт адміністративного судочинства». Акцентовано увагу на понятті, сутності та змістовному навантаженні адміністративної процесуальної правосуб'єктності.

Kлнtoвi choвa: адміністративне судочинство, учасник адміністративного судочинства, суб'скт адміністративного судочинства, сторона адміністративного судочинства, позивач, віпповідач.

\section{А н но т а ци я}

Киванов C. B. Понятийно-правовая характеристика сторон как участников административного судопроизводства. - Статья.

В статье проанализировано понятие, сущность и виды участников административного судопроизводства и места сторон в их системе. Особое внимание уделено соотношению понятий «участник административного судопроизводства» и "субъект административного 
судопроизводства». Акцентировано внимание на понятии, сущности и содержательной нагрузке административной процессуальной правосубъектности.

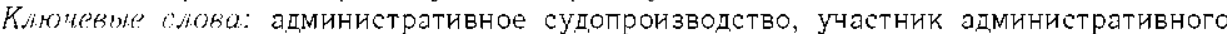
судопронзводства, субъект административного судопроизводства, сторона административного судопронзводства, истец, ответчнк.

\section{$\mathrm{S} u \mathrm{mll}$ a $\mathrm{r} y$}

Kloalon S. V. Terminological-legal characteristic of parties as participants of administrative judicial proceedings. - Article.

In the article there is analyzed the term, essence and types of participants of the administrative judicial proceedings and the place of parties in their system. Special attention is devoted to the correlation of the terms "participant of the administrative judicial proceedings" and "subject of the administrative judicial proceedings". The attention is accented on the term, essence and substantial burden of the administrative procedural legal personality.

Key words: administrative judicial proceedings, participant of the administrative judicial proceedings, subject of the administrative judicial proceedings, party of the administrative judicial proceedings, plaintiff, respondent. 